\title{
Prospects and Limitations Related to the Use of MicroRNA as a Biomarker of Epilepsy in Children: A Systematic Review
}

\author{
Beata Rzepka-Migut ${ }^{1}$ and Justyna Paprocka ${ }^{2, *}$ (D) \\ 1 Department of Pediatric Neurology and Pediatrics, St. Queen Jadwiga's Regional Clinical Hospital No. 2, \\ 35-301 Rzeszów, Poland; beata-rzepka@o2.pl \\ 2 Department of Pediatric Neurology, Faculty of Medical Science in Katowice, Medical University of Silesia, \\ 40-752 Katowice, Poland \\ * Correspondence: justyna.paprocka@interia.pl
}

check for

updates

Citation: Rzepka-Migut, B.; Paprocka,

J. Prospects and Limitations Related to the Use of MicroRNA as a Biomarker of Epilepsy in Children: A Systematic Review. Life 2021, 11, 26. https://doi.org/10.3390/life11010026

Received: 29 November 2020 Accepted: 29 December 2020 Published: 4 January 2021

Publisher's Note: MDPI stays neutral with regard to jurisdictional clai$\mathrm{ms}$ in published maps and institutional affiliations.

Copyright: (C) 2021 by the authors. Licensee MDPI, Basel, Switzerland. This article is an open access article distributed under the terms and conditions of the Creative Commons Attribution (CC BY) license (https:// creativecommons.org/licenses/by/ $4.0 /)$.

\begin{abstract}
Epilepsy is one of the most common neurological diseases in children. There is an unmet need for new objective methods that would facilitate and accelerate the diagnostic process, thus improving the prognosis. In many studies, the participation of microRNA in epileptogenesis has been confirmed. Therefore, it seems to be a promising candidate for this role. Scientists show the possibility of using microRNAs as diagnostic and predictive biomarkers as well as novel therapeutic targets. Children with epilepsy would benefit particularly from the use of this innovative method. However, the number of studies related to this age group is very limited. This review is based on 10 studies in children and summarizes the information collected from studies on animal models and the adult population. A total of 136 manuscripts were included in the analysis. The aim of the review was to facilitate the design of studies in children and to draw attention to the challenges and traps related to the analysis of the results. Our review suggests a high potential for the use of microRNAs and the need for further research.
\end{abstract}

Keywords: microRNA; miRNA; epilepsy; children; biomarker; prognosis; diagnosis

\section{Introduction}

Epilepsy is a chronic neurological disease with a heterogeneous clinical picture, characterized by the occurrence of asynchronous spontaneous and recurrent neural discharges. According to the World Health Organization (WHO), the disease affects more than 50 million people worldwide and the incidence in pediatric patients is estimated at 33-82/100,000 per year [1]. The diagnosis of epilepsy is based on the clinical picture presented by the patient that can be difficult to verify when there are no witnesses to the seizure. The diagnosis is also made on the basis of test results (electroencephalogram-EEG; neuroimaging studies). The experience of a physician is also of crucial importance in this respect [2]. Since the whole diagnostic process is largely subjective, objective studies are sought to prevent misdiagnosis. Scientists have high hopes for the discovery of the genetic background of epilepsy, which could be a reliable diagnostic tool. However, despite knowing nearly 200 genes associated with the disease in most patients, the genetic background is still unknown [3]. Rapid and accurate diagnosis, combined with effective treatment, is particularly important in the group of pediatric patients, as it would help to prevent severe sequelae of the disease such as exposure to mental disorders, including anxiety disorders, depression [4], delayed psychomotor development or cognitive disorders. Despite great effort, approximately $30 \%$ of patients are resistant to antiepileptic drugs, prompting further studies on the molecular basis of epilepsy and the implementation of targeted treatment.

One of the variants considered by scientists in the pathomechanism of epilepsy is the participation of microRNAs (miRNAs), i.e., short non-coding RNAs, approximately 18 to 25 nucleotides in length, acting at the post-transcriptional stage by being coupled to complementary mRNA, which results in degradation of the transcript or inhibition 
of protein synthesis. The expression of many genes is modulated by miRNAs. Single miRNAs target multiple proteins. At the same time, proteins can be regulated by a large number of miRNAs. More than $30 \%$ of the genes encoding proteins are regulated with miRNA [5]. Thus, manipulation of a single miRNA can interfere with a single pathway or simultaneously with many pathways [6]. The brain is the organ with the highest number of miRNAs, probably due to a complex mechanism of action [7]. Many studies have proven the contribution of miRNA to cell proliferation and migration, neuronal apoptosis and neuroinflammation.

Extracellular vesicles (EVs) are small membrane vesicles released by different cells into the microenvironment in response to physiological and pathological processes. In terms of diameter, there are three main classes: ectosomes (micro-vesicles), exosomes and apoptotic bodies. They have a function in intercellular communication but are also reported as a reservoir of biomarkers [8], contain lipids, RNA proteins, mRNAs and miRNAs [9]. Yan et al. conducted a study with patients suffering from mTLE-HS. The results showed the involvement of exosomal miRNAs as the seizure regulators and potent diagnostic biomarkers and therapeutic targets [10].

The aim of this review was the analysis of miRNA expression in children with epilepsy. The findings of animal models and adult patients can facilitate the design of studies in pediatric patients with the highest possible safety, comfort, and high reliability of the results obtained.

\section{Materials and Methods}

\subsection{Search Strategy}

A systematic search was conducted in the Pubmed database to identify the literature related to the involvement of miRNA in epilepsy. The following terms were used in the searching process: "miRNA", "miRNAs", "microRNA", "microRNAs" and "epilepsy". The search covered the period of 10 years back from 1 September 2020.

\subsection{Selection Criteria}

Manuscripts were reviewed for titles, abstracts, and the entire texts based on the following criteria. The inclusion criteria were as follows: (1) original papers; (2) epilepsy as a key topic of the paper; (3) studies comparing miRNA expression using PCR at different points in time or between groups without epilepsy, with epilepsy and refractory epilepsy; (4) manuscripts related to the influence of classical antiepileptic drugs on miRNA levels. The exclusion criteria were as follows: (1) reviews, case reports, methodological studies, editorials, commentaries, letters, hypotheses; (2) no available abstract; (3) manuscripts in a language other than English; (4) studies on cell lines; (5) material taken only from patients diagnosed with tuberous sclerosis complex (TSC), glioma, traumatic brain injury (TBI), cerebral ischaemia; (6) studies on changes in miRNA expression only on transgenic animals or those treated with novel methods aimed at modifying miRNAs.

\subsection{Development of the Review}

The analysis was conducted in the following steps. The first step was related to the analysis of selected papers based on titles and abstracts, the second step was connected with the analysis of full-text papers, and the last step included the analysis of the collected data. The data that met the inclusion criteria were entered into an Excel spreadsheet that included the following data: the title of a manuscript, animal/human model, group size, age, drugs, analyzed material, sampling time, PCR, type of miRNA and an increased or decreased level of miRNA expression in the group with epilepsy with the $p$-value.

\section{Results}

The preliminary search of the database showed 687 studies, of which 271 were verified based on the entire manuscript. A total of 136 studies were finally included in the analysis (Figure 1). Identification of miRNA with altered expression based on polymerase 
chain reaction (PCR) was performed for each study that was included in the review. We identified upregulation or downregulation. We also identified whether the study group was comprised of humans or animals, and the type of biological material in which miRNA expression was measured. As a result, we selected the most frequently analyzed miRNAs. We paid attention to studies which simultaneously compared the expression of the same miRNAs in humans and animals or in different tissues or biofluids. All the data were intended to facilitate the design of miRNA expression studies in pediatric patients.
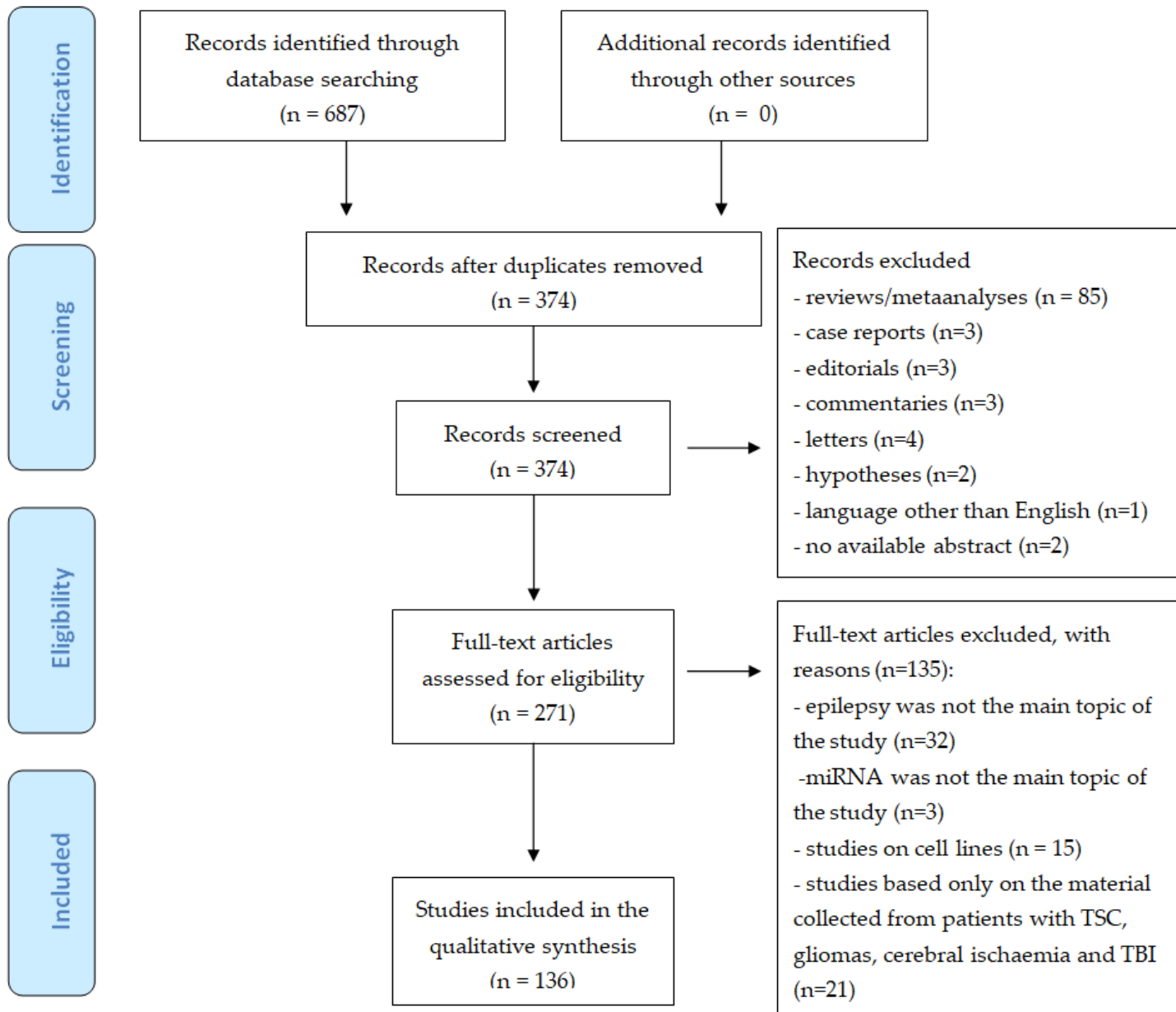

Full-text articles excluded, with reasons ( $\mathrm{n}=135)$ :

- epilepsy was not the main topic of the study $(\mathrm{n}=32)$

-miRNA was not the main topic of the study $(\mathrm{n}=3)$

- studies on cell lines $(n=15)$

- studies based only on the material collected from patients with TSC, gliomas, cerebral ischaemia and TBI $(\mathrm{n}=21)$

- studies on rodents with genetic predispositions or those subjected to additional procedures except for SE modelling ( $\mathrm{n}=14)$

- no comparisons of the measurement of miRNA expression using PCR between the study group and the control group presented in the research $(\mathrm{n}=50)$

Figure 1. Flow diagram of PRISMA for the strategy research and selection processes for this review. TSC: tuberous sclerosis complex, TBI: traumatic brain injury, SE: status epilepticus.

\subsection{The Level of Expression of MiRNA in Children with Epilepsy}

Based on our analysis, we identified only 10 manuscripts that included studies in children (Table 1). A total of 225 children with epilepsy were analyzed and 21 different miRNAs were studied. In more recent papers, there was growing tendency to use blood 
samples, while older studies were based on brain tissues collected intraoperatively from patients with refractory epilepsy. Temporal epilepsy was the most common diagnosis in the group of patients. Li et al. showed a significantly reduced expression of miR$15 a-5 p$ in children with epilepsy compared to healthy controls, which may indicate a potential significance in the pathogenesis of temporal lobe epilepsy (TLE). No significant differences were found between children with epilepsy and mesial sclerosis compared to children without these abnormalities. Additionally, no significant differences were observed between children with bilateral TLE compared to unilateral TLE. The change in expression did not correlate with the results of the EEG recordings or magnetic resonance imaging (MRI) studies [11].

Two studies included patients with cortical dysplasia. Tissues were collected for further examination during neurosurgery. The analysis of the miRNA expression profile was performed using microarrays. Next, miRNAs which showed an altered expression in the group with epilepsy was further verified using PCR. The results of both methods were consistent $[12,13]$.

Wang et al. measured the serum level of mir-139-5p in three groups of patients, i.e., children with newly diagnosed epilepsy who were not given any medication, children with refractory epilepsy, and healthy children. The expression of mir-139-5p decreased in the group of patients with newly diagnosed epilepsy compared to the controls. The results of reduced expression in the group of drug-resistant patients were also statistically significant compared to newly diagnosed patients [14].

Three independent studies analyzed the expression of miR-146a. The results of these studies were consistent and miR-146a showed increased expression in the group with epilepsy [15-17]. 
Table 1. Expression of selected miRNAs measured in a group of pediatric patients diagnosed with epilepsy.

\begin{tabular}{|c|c|c|c|c|c|c|c|c|c|}
\hline \multirow[b]{2}{*}{ References } & \multicolumn{3}{|c|}{ Children Diagnosed with Epilepsy } & \multicolumn{3}{|c|}{ Control Children } & \multirow[b]{2}{*}{ Samples } & \multicolumn{2}{|c|}{$\begin{array}{l}\text { MiRNA Expression in } \\
\text { Children with Epilepsy }\end{array}$} \\
\hline & Patients & $\begin{array}{l}\text { Number of } \\
\text { Patients }\end{array}$ & Age (Years) & Controls & $\begin{array}{c}\text { Number of } \\
\text { Controls }\end{array}$ & Age (Years) & & Up & Down \\
\hline Li, N. et al. 2020 [11] & TLE & 63 & $9.81 \pm 2.79$ & healthy & 67 & $10.13 \pm 2.46$ & serum & & miR-15a-5p \\
\hline \multirow{2}{*}{$\begin{array}{l}\text { Elnady, H.G. et al. } \\
2019 \text { [15] }\end{array}$} & \multirow{2}{*}{ epilepsy } & \multirow{2}{*}{30} & \multirow{2}{*}{ 5-15 } & \multirow{2}{*}{ Healthy } & \multirow{2}{*}{20} & \multirow{2}{*}{$5-15$} & \multirow{2}{*}{ plasma } & miR-146a & \\
\hline & & & & & & & & miR-106b & \\
\hline \multirow{2}{*}{$\begin{array}{l}\text { Wang, L. et al. } \\
2020 \text { [14] }\end{array}$} & refractory epilepsy & 26 & & NDE & 35 & & \multirow[b]{2}{*}{ serum } & & miR-139-5p \\
\hline & NDE & 35 & & $\begin{array}{l}\text { traumatic brain injury or } \\
\text { cerebrovascular malformation }\end{array}$ & 20 & & & & miR-139-5p \\
\hline $\begin{array}{l}\text { Wu, X. et al. } \\
2019 \text { [18] }\end{array}$ & TLE & 15 & $11.2 \pm 2.6$ & normal & 15 & $10.6 \pm 3.7$ & hippocampal Area CA3 & miR-135a-5p & \\
\hline \multirow{5}{*}{$\begin{array}{l}\text { Ren, L. et al. } \\
2016 \text { [16] }\end{array}$} & \multirow{5}{*}{ TLE } & \multirow{5}{*}{25} & & & \multirow{5}{*}{11} & & \multirow{5}{*}{ brain tissues } & miR-181a & \\
\hline & & & & & & & & miR-132 & \\
\hline & & & & & & & & miR-146a & \\
\hline & & & & & & & & miR-34a & \\
\hline & & & & & & & & miR-124 & \\
\hline \multirow{3}{*}{$\begin{array}{l}\text { Li, L. et al. } \\
2016[12]\end{array}$} & \multirow{3}{*}{ FCD type II B } & \multirow{3}{*}{5} & \multirow{3}{*}{ 50-112 months } & & & & \multirow{3}{*}{ brain tissues } & let-7f-1-3p & miR-6511b-5p \\
\hline & & & & & & & & miR-940 & \\
\hline & & & & & & & & miR-1825 & \\
\hline \multirow{5}{*}{$\begin{array}{l}\text { Lee, J.Y. et al. } \\
2014 \text { [13] }\end{array}$} & \multirow{5}{*}{ cortical dysplasia } & \multirow{5}{*}{8} & \multirow{5}{*}{$1-15$} & \multirow{5}{*}{ deep-seated lesions } & & & & miR-21 & \\
\hline & & & & & & & & miR-155 & \\
\hline & & & & & 3 & $2-13$ & brain tissues & miR-130b & \\
\hline & & & & & & & & miR-193b & \\
\hline & & & & & & & & miR-199b & \\
\hline $\begin{array}{l}\text { Ashhab, M.U. et al. } \\
\text { 2013 [19] }\end{array}$ & MTLE & 8 & $8-13$ & no history of any brain disease & 8 & $6-13$ & hippocampal tissues & miR-155 & \\
\hline & & & & & & & & miR-124 & \\
\hline Peng, J. et al. & MTIF & 5 & $8-12$ & no history of any brain disease & 5 & $8-12$ & hippocampal tissues & miR-134 & \\
\hline $2013[20]$ & & & & & & & & miR-132 & \\
\hline & & & & & & & & miR-21 & \\
\hline Omran, A. et al. 2012 [17] & MTLE & 5 & $8-12$ & no history of any brain disease & 5 & $8-12$ & hippocampal tissues & miR-146a & \\
\hline
\end{tabular}

NDE: Newly Diagnosed Epilepsy, FCD: Focal Cortical Dysplasia, MTLE: Mesial Temporal Lobe Epilepsy. 


\subsection{Animal versus Human Models}

Sampling at several time points in patients with epilepsy is still not very common. In our review, we identified four studies in which miRNA expression measurements were carried out at least twice. Brennan et al. analyzed plasma samples in patients with TLE which were taken during the seizure-free period (on admission and $24 \mathrm{~h}$ after the seizure). Based on their analysis, they found that the levels of most miRNAs were different between the two samples, which indicated their relationship to epilepsy rather than seizure. However, the levels of miR-142-5p were higher, which suggested that this miRNA may be transiently affected by acute seizure activity [21]. The same pattern of sampling was used by Raoof et al. who identified three miRNAs of high diagnostic significance [22]. In turn, Sun et al. collected serum during and after the seizure. They found overexpression of miR-378, miR-30a, miR-106b and miR-15a using RT-qPCR in the group of 90 patients [23]. Surges et al. collected blood at five different time points from patients with mesial temporal lobe epilepsy and compared changes in miRNA expression before and within $30 \mathrm{~min}, 3-6 \mathrm{~h}$, 20-28 $\mathrm{h}$ and 3-6 days after bilateral convulsive seizures (BCS). Additionally, 215 miRNAs were significantly altered within $30 \mathrm{~min}$ after BCS compared to baseline levels. Further analysis showed that the change was transient and associated with BCS due to the fact that no significant differences were found at any later time point [24].

Studies on animal models showed the importance of more frequent sampling for a better understanding of epileptogenesis. Table 2 shows the studies in which simultaneous sampling was carried out in the animal and human groups. Additionally, sampling was done more than once in the animal model and the level of expression was measured using PCR. In Table 2, presented below, we distinguish only those publications that examined miRNAs verified in a pediatric group suffering from epilepsy. 
Table 2. Expression of selected miRNAs measured in animal models of epilepsy and in group of patients diagnosed with epilepsy.

\begin{tabular}{|c|c|c|c|c|c|c|c|c|}
\hline References & $\begin{array}{l}\text { Experimental Animals and } \\
\text { Epilepsy Induction }\end{array}$ & Tissue & Time Points & $\begin{array}{l}\text { miRNA } \\
\text { Studied }\end{array}$ & $\begin{array}{l}\text { Level of Expression in a } \\
\text { Group with Epilepsy }\end{array}$ & Patients & Tissue & $\begin{array}{l}\text { Level of Expression in a } \\
\text { Group with Epilepsy }\end{array}$ \\
\hline \multirow{12}{*}{$\begin{array}{l}\text { Peng, J. et al. } 2013 \\
\text { [20] }\end{array}$} & \multirow{12}{*}{ PILO-induced SE in a rat model } & \multirow{12}{*}{$\mathrm{HP}$} & \multirow{4}{*}{$2 \mathrm{~h}$ post $\mathrm{SE}(\mathrm{AP})$} & miR-124 & up & \multirow{4}{*}{ MTLE } & \multirow{4}{*}{$\mathrm{HP}$} & up \\
\hline & & & & miR-134 & up & & & up \\
\hline & & & & miR-132 & up & & & up \\
\hline & & & & miR-21 & up & & & up \\
\hline & & & \multirow{4}{*}{3 weeks post SE (LP) } & $\mathrm{miR}-124$ & ns & & & \\
\hline & & & & miR-134 & ns & & & \\
\hline & & & & miR-132 & up & & & \\
\hline & & & & miR-21 & down & & & \\
\hline & & & \multirow{4}{*}{8 weeks post $\mathrm{SE}(\mathrm{CP})$} & miR-124 & up & & & \\
\hline & & & & miR-134 & up & & & \\
\hline & & & & miR-132 & up & & & \\
\hline & & & & miR-21 & up & & & \\
\hline \multirow{5}{*}{$\begin{array}{l}\text { Korotkov, A. et al. } \\
\quad 2020[25]\end{array}$} & \multirow{5}{*}{$\begin{array}{l}\text { tetanic stimulation-induced SE in } \\
\text { a rat model }(50 \mathrm{~Hz})\end{array}$} & \multirow{2}{*}{ DG } & 1 day post $\mathrm{SE}(\mathrm{AP})$ & \multirow{5}{*}{ miR-132 } & up & \multirow{5}{*}{ TLE-HS } & \multirow{5}{*}{$\mathrm{HP}$} & \multirow{5}{*}{ up } \\
\hline & & & 3-4 months post $\mathrm{SE}(\mathrm{CP})$ & & ns & & & \\
\hline & & \multirow{3}{*}{ CA1 } & 1 day post $\mathrm{SE}(\mathrm{AP})$ & & ns & & & \\
\hline & & & 1 week post SE (LP) & & ns & & & \\
\hline & & & 3-4 months post $\mathrm{SE}(\mathrm{CP})$ & & ns & & & \\
\hline \multirow{6}{*}{$\begin{array}{l}\text { Guo, J. et al. } 2014 \\
\text { [26] }\end{array}$} & \multirow{6}{*}{$\begin{array}{l}\text { lithium-PILO-induced epilepsy } \\
\text { in a rat model }\end{array}$} & \multirow{6}{*}{$\mathrm{HP}$} & $24 \mathrm{~h}$ post $\mathrm{SE}$ & \multirow{6}{*}{ miR-132 } & up & \multirow{6}{*}{ TLE } & \multirow{6}{*}{$\begin{array}{l}\text { temporal } \\
\text { neocor- } \\
\text { tex }\end{array}$} & \multirow{6}{*}{ down } \\
\hline & & & $72 \mathrm{~h}$ post $\mathrm{SE}$ & & ns & & & \\
\hline & & & $7 \mathrm{~d}$ post $\mathrm{SE}$ & & up & & & \\
\hline & & & $14 \mathrm{~d}$ post $\mathrm{SE}$ & & ns & & & \\
\hline & & & $30 \mathrm{~d}$ post $\mathrm{SE}$ & & ns & & & \\
\hline & & & $60 \mathrm{~d}$ post SE & & ns & & & \\
\hline
\end{tabular}


Table 2. Cont

\begin{tabular}{|c|c|c|c|c|c|c|c|c|}
\hline References & $\begin{array}{l}\text { Experimental Animals and } \\
\text { Epilepsy Induction }\end{array}$ & Tissue & Time Points & $\begin{array}{l}\text { miRNA } \\
\text { Studied }\end{array}$ & $\begin{array}{l}\text { Level of Expression in a } \\
\text { Group with Epilepsy }\end{array}$ & Patients & Tissue & $\begin{array}{l}\text { Level of Expression in } \\
\text { Group with Epilepsy }\end{array}$ \\
\hline \multirow{4}{*}{$\begin{array}{l}\text { Reschke, C.R. et al. } \\
2017 \text { [27] }\end{array}$} & \multirow{2}{*}{$\begin{array}{l}\text { PTZ model of generalized } \\
\text { tonic-clonic seizures in mice }\end{array}$} & cortex & \multirow{2}{*}{30 min after PTZ injection } & \multirow{4}{*}{ miR-134 } & ns & \multirow{4}{*}{ TLE } & \multirow{4}{*}{$\mathrm{HP}$} & \multirow{4}{*}{ up } \\
\hline & & $\mathrm{HP}$ & & & up & & & \\
\hline & \multirow{2}{*}{ PPS model of epilepsy in rats } & \multirow{2}{*}{$\mathrm{HP}$} & $24 \mathrm{~h}$ and 4 days after PPS & & ns & & & \\
\hline & & & 14 days after PPS & & ns & & & \\
\hline \multirow{2}{*}{$\begin{array}{l}\text { Alsharafi, W. et al. } \\
\text { 2015 [28] }\end{array}$} & \multirow{2}{*}{ PILO-induced SE in a rat model } & \multirow{2}{*}{$\mathrm{HP}$} & $2 \mathrm{~h}$ post $\mathrm{SE}(\mathrm{AP})$ & \multirow{2}{*}{ miR-135a } & up & \multirow{2}{*}{ TLE } & \multirow{2}{*}{$\mathrm{HP}$} & \multirow{2}{*}{ up } \\
\hline & & & 2 months post $\mathrm{SE}(\mathrm{CP})$ & & up & & & \\
\hline \multirow{3}{*}{$\begin{array}{c}\text { Alsharafi, W.A. et al. } \\
2016 \text { [29] }\end{array}$} & \multirow{3}{*}{ PILO-induced SE in a rat model } & \multirow{3}{*}{$\mathrm{HP}$} & 1 day after $\mathrm{SE}(\mathrm{AP})$ & \multirow{3}{*}{ miR-139-5p } & down & \multirow{3}{*}{ TLE } & \multirow{3}{*}{$\mathrm{HP}$} & \multirow{3}{*}{ down } \\
\hline & & & 7 days after SE (LP) & & ns & & & \\
\hline & & & 60 days after $\mathrm{SE}(\mathrm{CP})$ & & down & & & \\
\hline \multirow{3}{*}{$\begin{array}{l}\text { Omran, A. et al. } \\
2012 \text { [17] }\end{array}$} & \multirow{3}{*}{$\begin{array}{l}\text { lithium-PILO-induced SE in a rat } \\
\text { model }\end{array}$} & \multirow{3}{*}{$\mathrm{HP}$} & $2 \mathrm{~h}$ post $\mathrm{SE}(\mathrm{AP})$ & \multirow{3}{*}{ miR-146a } & ns & \multirow{3}{*}{ MTLE } & \multirow{3}{*}{$\mathrm{HP}$} & \multirow{3}{*}{ up } \\
\hline & & & 3 weeks post SE (LP) & & up & & & \\
\hline & & & 8 weeks post $\mathrm{SE}(\mathrm{CP})$ & & up & & & \\
\hline & & & 1 day post $\mathrm{SE}(\mathrm{AP})$ & & up & & & \\
\hline & & PHC & 3-4 months post $\mathrm{SE}(\mathrm{CP})$ & & up & & & \\
\hline & & & $2 \mathrm{~h}$ after post $\mathrm{SE}(\mathrm{AP})$ & & ns & & & \\
\hline Li, T.R. et al. & KA-induced SE in o rat model & HP & 7 days post SE (LP) & $\mathrm{miR}-155$ & up & TIF_HS & HP & up \\
\hline 2018 [31] & KA-induced SE in a rat model & $\mathrm{HP}$ & 21 days post $\mathrm{SE}$ (LP) & & up & & & \\
\hline & & & 60 days post $\mathrm{SE}(\mathrm{CP})$ & & up & & & \\
\hline & & & 0 day post-SE & & ns & & & \\
\hline & & & 1 day post-SE & & ns & & & \\
\hline & & CA1 & 14 days post-SE & & ns & & & \\
\hline & & & 30 days post-SE & & ns & & & \\
\hline & & & 60 days post-SE & & ns & & & 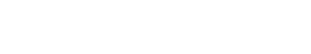 \\
\hline 2018 [32] & PILO-induced TLE in a rat model & & 0 day post-SE & miR-155 & ns & TLE & CA3 & up \\
\hline & & & 1 day post-SE & & up & & & \\
\hline & & CA3 & 14 days post-SE & & up & & & \\
\hline & & & 30 days post-SE & & up & & & \\
\hline & & & 60 days post-SE & & up & & & \\
\hline
\end{tabular}


Table 2. Cont.

\begin{tabular}{|c|c|c|c|c|c|c|c|c|}
\hline References & $\begin{array}{l}\text { Experimental Animals and } \\
\text { Epilepsy Induction }\end{array}$ & Tissue & Time Points & $\begin{array}{l}\text { miRNA } \\
\text { Studied }\end{array}$ & $\begin{array}{l}\text { Level of Expression in a } \\
\text { Group with Epilepsy }\end{array}$ & Patients & Tissue & $\begin{array}{l}\text { Level of Expression in a } \\
\text { Group with Epilepsy }\end{array}$ \\
\hline \multirow{3}{*}{$\begin{array}{l}\text { Ashhab, M.U. et al. } \\
2013 \text { [19] }\end{array}$} & \multirow{3}{*}{$\begin{array}{l}\text { lithium-PILO-induced SE in a rat } \\
\text { model }\end{array}$} & \multirow{3}{*}{$\mathrm{HP}$} & $2 \mathrm{~h}$ post $\mathrm{SE}(\mathrm{AP})$ & \multirow{3}{*}{ miR-155 } & up & \multirow{3}{*}{ MTLE } & \multirow{3}{*}{$\mathrm{HP}$} & \multirow{3}{*}{ up } \\
\hline & & & 3 weeks post SE (LP) & & ns & & & \\
\hline & & & 8 weeks post $\mathrm{SE}(\mathrm{CP})$ & & up & & & \\
\hline \multirow{8}{*}{$\begin{array}{l}\text { Ren, L. et al. } \\
2016 \text { [16] }\end{array}$} & \multirow{8}{*}{$\begin{array}{l}\text { lithium-PILO-induced SE in a rat } \\
\text { model }\end{array}$} & \multirow{8}{*}{$\mathrm{HP}$} & $24 \mathrm{~h}$ post SE & \multirow{4}{*}{ miR-181a } & up & \multirow{8}{*}{ TLE } & \multirow{8}{*}{$\begin{array}{l}\text { brain } \\
\text { tissues }\end{array}$} & \multirow{4}{*}{ up } \\
\hline & & & 7 days post $\mathrm{SE}$ & & up & & & \\
\hline & & & 14 days post SE & & up & & & \\
\hline & & & 3 months post SE (TLE) & & up & & & \\
\hline & & & & miR-132 & up & & & up \\
\hline & & & & miR-146a & up & & & up \\
\hline & & & & miR-34a & up & & & up \\
\hline & & & & miR-124 & up & & & up \\
\hline
\end{tabular}

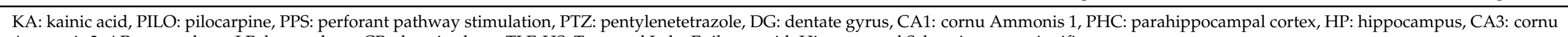
Ammonis 3, AP: acute phase, LP: latent phase, CP: chronic phase, TLE-HS: Temporal Lobe Epilepsy with Hippocampal Sclerosis, ns: no significance. 
Brennan et al. used three different animal models of status epilepticus. The serum samples were collected before the seizure, during epileptogenesis, and in chronic TLE. Five miRNAs potentially significant for epilepsy were identified. These miRNAs were verified in patients with TLE. Statistically significant results were found in three cases, which showed the same expression profile in each model. However, those authors we were unable to detect a single miRNA that would be characteristic at a given time point, but they noted that miRNA dysregulation was usually present in chronically epileptic mice [21].

The expression level of miR-155 was the subject of four studies. Korotkov et al. analyzed miR-155 expression in a rat model of SE at three different time points and found an increase in expression at all time points and all types of tissues [30]. The same miRNA was studied by Li et al. at four time points. The increase in miR-155 was noted in the first sample taken after the seizure, although the results were not statistically significant. The highest level of expression was found on day 7 and then it gradually decreased [31]. Huang et al. reported an increase in miR-155 level in CA3 after the seizure that peaked on day 14. The results were not statistically significant for CA1 [32].

Reschke et al. conducted an analysis of miR-134 expression levels in two different models of epilepsy and found an increase in expression $30 \mathrm{~min}$ after the administration of pentylenetetrazol in hippocampal samples of mice. Their results were consistent with those observed in the hippocampus of patients surgically treated for TLE. However, the study results conducted at the early time points ( $24 \mathrm{~h}$, 4 days after the performed pathway stimulation) and at the late time point (14 days after the performed pathway stimulation) on a rat model of epilepsy were not statistically significant [27].

Zheng et al. was the only one to use cerebrospinal fluid to measure miR-219 and found a decrease in the levels of miR-219 in patients with epilepsy. Additionally, miR-219 levels decreased in hippocampal tissues in an animal model of epilepsy. However, changes in expression measured in cortical tissues showed no significant differences compared to the control group [33].

An additional animal model was present in 5 of 10 studies (Table 1), but four samples were collected several times $[16,17,19,20]$. Based on the literature, Ren et al. identified five miRNAs with possible significance for epilepsy. They confirmed altered expression of miR-132, miR-146a, miR-181a, miR-34a, and miR-124 in children with TLE and in a rat model. The most significant changes in the level of expression were found for miR-181. Therefore, the scope of the study was extended by the measurement at four time points, which resulted in significantly higher results in each time point compared to the control group [16].

The studies of Peng et al., Ashhab et al. and Omran et al. were based on a rat model of epilepsy in which three phases of development of mesial temporal lobe epilepsy were identified (acute phase associated with seizures, latent seizure-free phase and chronic phase associated with seizures). Of note, the expression of miRNA in children reflected the chronic stage in a rat model, and the results of both study groups were consistent $[17,19,20]$.

\subsection{Expression of MiRNAs in Blood and Other Biological Materials}

To assess miRNA expression, it is easier to obtain blood samples than brain tissue. Therefore, we analyzed seven studies in which the same miRNAs were assayed in different materials of human origin in the same diseases (Table 3). 
Table 3. MicroRNA expression measured in different biological materials in patients with the same clinical diagnosis.

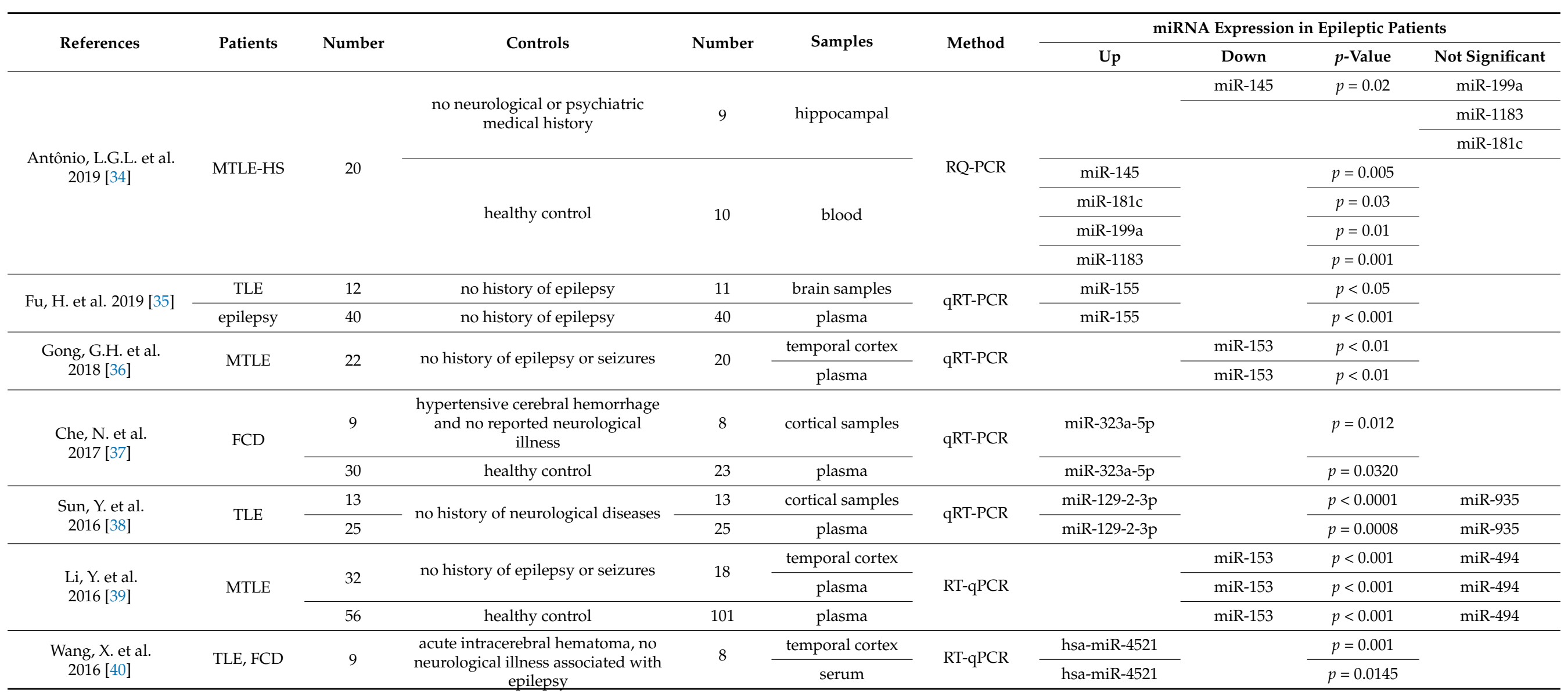


Interesting results were obtained by Antônio et al., who examined the expression of four miRNAs in patients with MTLE in blood and hippocampal tissue samples and two comparison groups, i.e., healthy control-blood samples and human tissues collected at autopsy. In blood samples, all miRNAs showed increased expression. However, in hippocampal tissues only miR-145 levels showed statistical significance compared to the control group but with the opposite direction of change than in the bioliquid [34].

Sun et al. measured the level of miR-129-2-3p and miR-935 in the brain tissue and plasma in two groups of patients with refractory temporal epilepsy and selected controls and achieved the same direction of change [38]. The same study regimen was used by Che et al. who analyzed the level of miR-323a-5p in patients with focal cortical dysplasia [37] and Fu et al. who studied miR-155 level in patients with TLE [35].

Li et al. found a decreased expression of miR-153 and miR-494 in brain tissue samples and a decreased level of miR-153 in plasma. Following neurosurgery, no significance of miR-494 was found in the same surgical patients with MTLE compared to the control group. The study was extended to a larger group of patients and matched controls. The results obtained from plasma samples were consistent [39].

Wang et al. evaluated hsa-miR-4521 level in patients with FCD and the control group due to an emergency neurosurgical procedure based on temporal cortex tissue and serum. In both samples, upregulated expression of hsa-miR-4521 was found in patients with epilepsy [40].

\subsection{Impact of Drugs on MiRNA Levels}

The opinions on the results of the impact of antiepileptic therapy on a reliable miRNA expression level are not consistent. Brennan et al. analyzed the effect of carbamazepine and diazepam on miRNA expression at two time points, before and after 3 days of therapy. None of the five miRNAs showed a statistically significant change. A different result was achieved when antiepileptic drugs were used. These drugs (i.e., antisense oligonucleotide inhibitors, also known as antagomirs) directly targeted miRNAs and hence altered the level of some of the miRNAs [21]. The same set of drugs used for 3 days in a mouse model of epilepsy was used by Raoof et al. The expression levels of miR-27a-3p, miR-328-3p, and miR-654-3p showed no changes in plasma after therapy [22]. Different results were obtained by Wang et al. who studied the expression level of miR-134 in patients with newly diagnosed epilepsy. Significantly higher levels were found only in patients with severe epilepsy compared to the control group. After one month of treatment with valproic acid, the mean level of miR-134 was significantly decreased in patients with severe epilepsy $(p<0.05)$ [41].

Haenisch et al. administered phenobarbital to rats twice a day for 2 weeks, the levels of the miRNAs measured did not change significantly [42]. In addition, there is evidence of the potential use of miR-155 as a biomarker for the efficacy of antiepileptic therapy [35].

\subsection{The Most Important MiRNA in the Context of Epilepsy}

Based on our analysis of the studies, we identified potential miRNAs related to epilepsy. However, we paid attention to miRNAs of the most diagnostic and prognostic significance.

Table 4 shows miRNAs whose expression correlates with the clinical picture. 
Table 4. Expression of miRNAs whose correlates with the clinical characteristics.

\begin{tabular}{|c|c|c|}
\hline References & miRNA & Clinical Characteristics \\
\hline Elnady, H.G. et al. 2019 [15] & miR-146a & age $(p=0.007)$ \\
\hline \multirow{5}{*}{ Organista-Juárez, D. et al. 2019 [43] } & miR-1260 & age $(p=0.018)$ \\
\hline & miR-1298 & age $(p=0.022)$ \\
\hline & \multirow{2}{*}{ miR-146a } & seizure frequency $(p=0.009)$ \\
\hline & & number of antiepileptic drugs $(p=0.03)$ \\
\hline & $\operatorname{miR}-451$ & number of antiepileptic drugs $(p=0.046)$ \\
\hline Shen, C.H. et al. 2019 [44] & miR-145-5p & $\begin{array}{l}\text { earlier age at epilepsy onset }(p=0.024) \\
\text { seizure frequency }(p=0.020) \\
\text { past history (head trauma, encephalitis) } \\
\qquad(p=0.014)\end{array}$ \\
\hline Gong, G.H. et al. 2018 [36] & $\operatorname{miR}-153$ & $\begin{array}{l}\text { seizure frequency }(p=0.018) \\
\text { Engel classification }(p<0.01)\end{array}$ \\
\hline Huang, L.G. et al. 2018 [32] & $\operatorname{miR}-155-5 p$ & $\begin{array}{l}\text { hippocampal sclerosis }\left(p=4.03 \times 10^{-5}\right) \\
\text { Engel classification }\left(p=3.54 \times 10^{-5}\right) \\
\text { seizure frequency }(p=0.028)\end{array}$ \\
\hline Wang, X. et al. 2017 [41] & miR-134 & $\begin{array}{c}\text { seizure severity ( } p=0.016 \text { moderate } \\
\text { seizure group, } p=0.003 \text { severe seizure } \\
\text { group) }\end{array}$ \\
\hline Yan, S. et al. 2017 [10] & miR-8071 & $\begin{array}{c}\text { disease duration }(p=0.0073) \\
\text { seizure frequency }(p=0.0316)\end{array}$ \\
\hline Che, N. et al. 2017 [37] & $\operatorname{miR}-323 a-5 p$ & $\begin{array}{c}\text { disease duration }(p=0.014) \\
\text { seizure frequency }(p=0.043) \\
\text { poor prognosis }(p=0.028) \\
\text { effectiveness of surgery }(p=0.005)\end{array}$ \\
\hline Surges, R. et al. 2016 [24] & miR-143-3p, miR-145-5p & total seizure duration \\
\hline Sun, J. et al. 2016 [23] & miR-30a & seizure frequency $(p<0.01)$ \\
\hline An, N. et al. 2016 [45] & $\operatorname{miR}-106 b$ & $\begin{array}{l}\text { seizure severity using the National } \\
\text { Hospital Seizure Severity Scale (NHS3) }\end{array}$ \\
\hline Sun, Y. et al. 2016 [38] & $\operatorname{miR}-129-2-3 p$ & $\begin{array}{l}\text { Engel classification }(p=0.005) \\
\text { seizure frequency }(p=0.027)\end{array}$ \\
\hline Wang, J. et al. 2015 [46] & $\operatorname{miR}-301 a-3 p$ & $\begin{array}{l}\text { seizure severity using the National } \\
\text { Hospital Seizure Severity Scale (NHS3) } \\
\qquad\left(p=6.2 \times 10^{-9}\right)\end{array}$ \\
\hline
\end{tabular}

We also analyzed miRNAs as potential biomarkers for refractory epilepsy (Table 5), diagnostic biomarkers (Table 6) and prognostic biomarkers (Table 7). To identify the studies with the highest importance, we focused on studies that used the analysis of receiver operating characteristic (ROC) curves. The closer the area under the curve (AUC) to 1, the higher the sensitivity and specificity of a diagnostic marker.

Table 5. miRNA as a potential biomarker of drug resistance.

\begin{tabular}{ccc}
\hline References & miRNA & AUC \\
\hline Leontariti, M. et al. 2020 [47] & miR-146a & 0.640 \\
Shen, C.H. et al. 2019 [44] & miR-134 & 0.617 \\
Wang, X. et al. 2016 [40] & miR-145-5p & 0.632 \\
Li, Y. et al. 2016 [39] & miR-153 & 0.718 \\
Sun, Y. et al. 2016 [38] & miR-129-2-3p & \\
Wang, J. et al. 2015 [46] & miR-301a-3p & 0.778 \\
\hline
\end{tabular}


Table 6. miRNA as a potential diagnostic biomarker for epilepsy.

\begin{tabular}{|c|c|c|c|c|c|}
\hline References & miRNA & Diagnostic Marker & Sensitivity & Specificity & AUC \\
\hline Ioriatti, E.S. et al. 2020 [48] & $\operatorname{miR}-328-3 p$ & MTLE-HS & $89.30 \%$ & $90.90 \%$ & 0.935 \\
\hline Brennan, G.P. et al. 2020 [21] & $\begin{array}{c}\text { miR-93a-5p, miR-199a, } \\
\text { miR-574-3p }\end{array}$ & TLE & & & $0.88-0.86$ \\
\hline Martins-Ferreira, R. et al. 2020 [49] & miR-146a, miR-155, miR-132 & GGE & $73 \%$ & $80 \%$ & 0.850 \\
\hline Li, N. et al. 2020 [11] & $\operatorname{miR}-15 a-5 p$ & TLE & $82.50 \%$ & $88.10 \%$ & 0.908 \\
\hline Shen, C.H. et al. 2019 [44] & $\operatorname{miR}-145-5 p$ & MTLE & & & 0.829 \\
\hline Elnady, H.G. et al. 2019 [15] & $\begin{array}{l}\text { miR-106b } \\
\text { miR-146a }\end{array}$ & epilepsy & $\begin{array}{c}80 \% \\
73.70 \%\end{array}$ & $\begin{array}{l}80 \% \\
60 \% \\
\end{array}$ & $\begin{array}{l}0.885 \\
0.763\end{array}$ \\
\hline Raoof, R. et al. 2018 [22] & $\begin{array}{c}\text { miR-27a-3p } \\
\text { miR-328-3p } \\
\text { miR-654-3p } \\
\text { miR-27a-3p, miR-328-3p, } \\
\text { miR-654-3p }\end{array}$ & $\begin{array}{l}\text { TLE } \\
\text { GGE } \\
\text { TLE } \\
\text { TLE } \\
\text { GGE } \\
\text { TLE } \\
\text { GGE }\end{array}$ & & & $\begin{array}{l}0.630 \\
0.730 \\
0.630 \\
0.870 \\
0.720 \\
0.640 \\
0.740\end{array}$ \\
\hline Raoof, R. et al. 2017 [50] & $\begin{array}{c}\text { miR-451a, mir-21-5p } \\
\text { miR-19b-3p, miR-21-5p } \\
\text { miR-451a }\end{array}$ & TLE and SE & & & $\begin{array}{l}0.850 \\
0.830\end{array}$ \\
\hline Avansini, S.H. et al. 2017 [51] & miR-134 & MTLE & $75 \%$ & $58 \%$ & 0.671 \\
\hline Yan, S. et al. 2017 [10] & miR-8071 & MTLE-HS & $83.33 \%$ & $96.67 \%$ & 0.9316 \\
\hline An, N. et al. 2016 [45] & $\begin{array}{l}\text { miR-106b } \\
\text { miR-146a }\end{array}$ & epilepsy & & & 0.887 \\
\hline Wang, J. et al. 2015 [52] & miR-106b-5p & epilepsy & $80.30 \%$ & $81.20 \%$ & 0.882 \\
\hline
\end{tabular}

Table 7. miRNA as a potential prognostic biomarker of epilepsy.

\begin{tabular}{cccc}
\hline References & miRNA & Prognostic Biomarker & AUC \\
\hline Ioriatti, E.S. et al. 2020 [48] & miR-654-3p & MTLE-HS & 0.736 \\
Shen, C.H. et al. 2019 [44] & miR-145-5p & MTLE & 0.829 \\
\hline
\end{tabular}

Leontariti et al. showed elevated serum levels of miR-146a and miR-134 in drugresistant patients and found that they were a risk factor for developing refractory epilepsy independently of other clinical aspects such as family history, gender, age at the first seizure, or duration of epilepsy. It is suggested that patient care combined with the assessment of the levels of these miRNAs could improve early prognosis in this group of patients [47]. The inhibitory effect on the development of drug resistance by targeting MRP1 was attributed to miR-139-5p [14].

Chen et al. identified miR-434-3p and miR-133a-3p as potential circulating biomarkers of epileptogenesis [53]. However, Raoof et al. considered miR-328-3p (AUC $=0.9)$ and miR-27a-3p $($ AUC $=0.88)$ potential biomarkers of seizure [22].

\section{Discussion}

Epilepsy is a common neurological condition in pediatric patients [54], and making an accurate diagnosis is a challenge in this age group. Uldall et al. conducted a study verifying the diagnosis of epilepsy in a group of 223 children, of whom $86 \%$ were on antiepileptic drugs. The review of the clinical picture (including EEG recordings) showed that $39 \%$ of children were found not to have epilepsy and $15 \%$ of children had their medication tapered off. The study indicated a large scale of misdiagnosis [55]. Young children are particularly susceptible to seizures, especially SE. The etiology of this phenomenon is multifactorial. 
Internal and external factors are distinguished. The former include, e.g., immaturity of intrinsic endogenous networks which lead to seizure termination, increase in local excitability, whereas the latter include hypoxic-ischemic insult, fever, or inflammation [56]. Epileptogenesis is a complex process that is initiated by traumatic brain injury, which results in many cellular and molecular changes that lead to spontaneous seizures [57]. In the treatment of epilepsy, it is crucial to reduce the seizure duration and its frequency, which is associated with neuroprotection [11]. However, about 3 in 10 patients are drug-resistant. According to the definition proposed by the International League Against Epilepsy (ILAE), the above is related to the failure of therapy with two well-tolerated, appropriately selected antiepileptic drugs. Understanding the mechanism of epileptogenesis at an early stage could help to develop a therapy that would prevent or modify these changes [20].

The above problems affect the intensive search for new diagnostic, prognostic and therapeutic methods. As described above, there is a wide database of miRNAs which undergo expression changes in patients with epilepsy. Using them as diagnostic biomarkers would not only allow for a more accurate diagnosis of epilepsy, but it would also accelerate the diagnosis time and reduce costs, thus improving the quality of life of patients and their families. It has been proven that miRNA is stable in various biological materials and it reflects the damage to the central nervous system (CNS) [58]. Determination of miRNA levels in blood is an easy, quick, accessible, and slightly invasive method that offers new perspectives. Firstly, it is possible to conduct more extensive studies on the pediatric population. Due to the dynamic expression pattern, sampling at more than one time point provides researchers with information which of the dysregulated miRNAs can be a potential marker of acute seizure (change in the miRNA level after seizure) or epilepsy (before and after a seizure, the miRNA level will not change significantly) compared to the control. Greater availability of the comparative material from healthy controls will objectify the results compared to the studies in which hippocampal tissues were used. These tissues were collected during surgical treatment of epilepsy. It will also be possible to compare them with the control group in which brain tissues were obtained from neurosurgical procedures performed due to other indications or from post-mortem examinations. Roncon et al. compared miRNA expression in three groups, i.e., brain tissues intraoperatively collected from patients with epilepsy, brain tissues of patients with epilepsy taken during post-mortem examinations, and brain tissues from post-mortem examinations from patients without a history of seizures. Hierarchical clustering showed that the samples obtained from post-mortem examinations of patients with epilepsy were segregated with the other post-mortem tissues. Despite a small study group, the origin of the tissue may be more significant than the underlying pathology [59]. In turn, a study on a mouse model of epilepsy (in which the autopsy delay was intentionally induced) showed no significant differences in miRNA levels measured immediately, $4 \mathrm{~h}$ and $8 \mathrm{~h}$ post-mortem [60]. Bencurova et al. presented similar results of miRNA stability in autopsy samples [61]. To our knowledge, the usefulness of miRNA determination in saliva samples in patients with epilepsy has not been investigated, but studies conducted in a pediatric group with a diagnosis of spectrum autism disorder presented promising results for the use of this bioliquid [5,62].

All the presented reports testify to the need to standardize the studies on the use of miRNA. Liguori et al. conducted a study on a pediatric group of patients suffering from multiple sclerosis (MS). The researchers pointed out the limitations of the use of microarrays and the possibilities offered by the use of HighThroughput Next-generation Sequencing (HT-NGS), which enables miRNA and mRNA profiling [63].

The part of miRNAs can be considered prognostic biomarkers of epilepsy, drug resistance, surgical prognosis and effectiveness of therapy. Predicting resistance to treatment is of crucial importance, since through a precisely selected, effective and timely therapy, patients can be protected against long-term complications of epileptic seizures. New epileptic subtypes with a characteristic course and prognosis may be identified using miRNAs. Animal studies are also promising, as they modify the expression of miRNAs (through in- 
novative methods) with a simultaneous follow-up of seizures or histopathological changes. Therefore, miRNAs are potential molecular targets for drug design. An innovative approach modifying the level of miRNAs is the use of antagomirs (antisense oligonucleotides that bind and block miRNAs) or agomirs (miRNA imitators that increase its level). Of the entire pool of miRNAs that have been linked to epilepsy, only a small part have been manipulated. The use of an antagomir to suppress the expression of miR-134 resulted in prolonged seizure suppression and neuroprotective effects $[27,64,65]$, while the use of a nasally administered antagomir to suppress miR $155-5 p$ reduced the severity of seizures, prolonged the delay to generalized seizures, and increased the percentage of seizure-free animals by $20 \%$ [66]. The use of miR-34a antagomir in the Hu et al. study contributed to increased neuronal survival and had a neuroprotective effect [67], while the Sano et al. study showed little effect on apoptotic changes and did not reduce neuronal death in mouse models of moderate and severe epileptic condition [68]. Other researchers have used the miR-181, miR-132, miR-155-5p antagomirs to achieve a neuroprotective effect and reduce seizure-induced neuronal death $[16,32,69]$. Less research has been devoted to the use of agomirs, Wang et al. evaluated the effect of injecting miR-146a agomir and miR-146a antagomir in a group of rats in which SE was induced with lithium chloride and pilocarpine. The rats that received the antagomir presented longer seizures and shorter latency periods; in the group treated with agomir, the results were reversed [70]. Zhang et al. indicated that suppressing the expression of miR-146a may improve drug resistance and weaken pathological changes in patients with refractory epilepsy [71]. In the Iori et al. study, the use of miR-146a agomir reduced seizure severity and neuronal excitability [72].

The research on miRNAs is of growing interest. The fact that miRNA names depend on the order in which they are detected and are assigned according to the numerical system proves how large our database is [73]. The exception to this rule is the let-7 family. The data presented in the above review are only a fragment of the studied miRNAs, which have been associated with epilepsy and provide a basis for further research on the function of these molecules in the mechanisms of epileptogenesis. However, the discussion of all miRNAs exceeds the possibilities of the presented review, but we would like to present some of the possible options for regulating gene expression in epilepsy.

The miR-146a has been associated with the IL-1/Toll-like receptor pathway (IL1R1/TLR4), its activation results in a lower seizure threshold and neuronal hyperactivity, which promotes epileptogenesis. The experimental use of miR-146a agomir lowers the levels of two key proteins: IRAK-2 and TRAF-6, which mediate IL-1R1/TLR4 signaling [72].

Alsharafi et al., using the experimental TLE model, showed that the miR-139-5p targets the enthralling alpha 2 subunit of the neuronal NMDA receptor NMDA-NM2A. The role of NMDA receptors is to participate in the neurotransmission and plasticity of neurons, and their activation is associated with the generation and maintenance of seizures and death of neurons in the hippocampus area [29]. Another target gene for miR-139$5 \mathrm{p}$ is multidrug resistance-associated protein 1 (MRP1). Modifications involving downregulation of MRP1 or overexpression of miR-139-5p may have neuroprotective effects by increasing the survival of neurons, alleviating their damage and reducing apoptosis [14].

MiR-155 has been found to be a strong regulator of Sestrin-3, it is a gene associated with oxidative stress prevention, and the resulting interdependence may provide a molecular basis for the development of seizures during brain injury [32].

MiR-34a and miR-181a affect apoptosis-related genes such as bcl-2 and caspase$3[16,67,74]$. In turn, the combined action of miR-137 and miR-124 regulates the expression of BCL2L13 (atypical BCL2 protein), which controls the release of cytochrome C and caspase- 3 activity in nerve stem/progenitor cells and may affect early neurogenic response after the onset of a seizure [75].

The EpimiRBase is a database that provides up-to-date information on changes and the role of miRNAs in epilepsy. In addition, we have access to other databases such as miRTarBase, TargetScan to search for potential miRNA targets. 
Despite the enormous prospects and promising study results, the route of miRNAs from the laboratory to widespread clinical use is still very long.

\section{Limitations}

This review has several limitations, including the small number of studies on the pediatric population which considers a known genetic background of epilepsy, the comparison of the results of miRNA expression in the group with epilepsy versus healthy controls, autopsy samples or samples collected during major neurosurgical procedures, an uncertain effect of antiepileptic drugs on changes in miRNA expression and the heterogeneity of the study groups.

\section{Conclusions}

MiRNAs are a promising novel diagnostic and predictive tool and a potential therapeutic target. Further studies on the pediatric population are warranted, because still little is known about this age group. In addition, despite a significant database of miRNAs with dysregulated expression, their relationship to epileptogenesis remains unclear.

Author Contributions: Conceptualization, J.P., B.R.-M.; Methodology, J.P., B.R.-M.; Formal Analysis, B.R.-M.; Data Curation, B.R.-M.; Writing-Original Draft Preparation, B.R.-M., J.P.; Writing-Review and Editing, J.P.; Visualization, B.R.-M., J.P.; Supervision, J.P.; Project Administration, J.P. All authors have read and agreed to the published version of the manuscript.

Funding: This research received no external funding.

Data Availability Statement: Publicly available datasets were analyzed in this study. This data can be found here: https://pubmed.ncbi.nlm.nih.gov/.

Acknowledgments: We wish to thank Arkadiusz Badziński DHSc, an authorized medical translator and interpreter, for his assistance in the translation of the manuscript.

Conflicts of Interest: The authors declare no conflict of interest.

$\begin{array}{ll}\text { Abbreviations } & \\ \text { AP } & \text { acute phase } \\ \text { CA1 } & \text { cornu Ammonis 1 } \\ \text { CA3 } & \text { cornu Ammonis 3 } \\ \text { CP } & \text { chronic phase } \\ \text { CSF } & \text { cerebrospinal fluid } \\ \text { DG } & \text { dentate gyrus } \\ \text { FCD } & \text { Focal Cortical Dysplasia } \\ \text { GGE } & \text { Genetic Generalized Epilepsies } \\ \text { HP } & \text { hippocampus } \\ \text { KA } & \text { kainic acid } \\ \text { LP } & \text { latent phase } \\ \text { MTLE } & \text { Mesial Temporal Lobe Epilepsy } \\ \text { MTLE-HS } & \text { Mesial Temporal Lobe Epilepsy with Hippocampal } \\ \text { NDE } & \text { Sclerosis } \\ \text { NS } & \text { Newly Diagnosed Epilepsy } \\ \text { PHC } & \text { no significance } \\ \text { PILO } & \text { parahippocampal cortex } \\ \text { PPS } & \text { pilocarpine } \\ \text { PTZ } & \text { perforant pathway stimulation } \\ \text { SE } & \text { pentylenetetrazole } \\ \text { TLE } & \text { status epilepticus } \\ \text { TLE-HS } & \text { Temporal Lobe Epilepsy } \\ & \text { Temporal Lobe Epilepsy with Hippocampal Sclerosis }\end{array}$




\section{References}

1. Nickels, K.C.; Wong-Kisiel, L.C.; Moseley, B.D.; Wirrell, E.C. Temporal lobe epilepsy in children. Epilepsy Res. Treat. 2012, 2012, 849540. [CrossRef] [PubMed]

2. Chen, S.D.; Pan, H.Y.; Huang, J.B.; Liu, X.P.; Li, J.H.; Ho, C.J.; Tsai, M.H.; Yang, J.L.; Chen, S.F.; Chen, N.C.; et al. Circulating MicroRNAs from Serum Exosomes May Serve as a Putative Biomarker in the Diagnosis and Treatment of Patients with Focal Cortical Dysplasia. Cells 2020, 9, 1867. [CrossRef] [PubMed]

3. Nolan, D.; Fink, J. Genetics of epilepsy. In Handbook of Clinical Neurology; Geschwind, D.H., Paulson, H.L., Klein, C., Eds.; Elsavier: Amsterdam, The Netherlands, 2018; Volume 148, pp. 467-491.

4. Josephson, C.B.; Jetté, N. Psychiatric comorbidities in epilepsy. Int. Rev. Psychiatry 2017, 29, 409-424. [CrossRef] [PubMed]

5. Lassandro, G.; Ciaccia, L.; Amoruso, A.; Palladino, V.; Palmieri, V.V.; Giordano, P. Focus on MicroRNAs as Biomarker in Pediatric Diseases. Curr. Pharm. Des. 2020, 2020. [CrossRef] [PubMed]

6. Ebert, M.S.; Sharp, P.A. Roles for microRNAs in conferring robustness to biological processes. Cell 2012, 149, 515-524. [CrossRef] [PubMed]

7. Kosik, K.S. The neuronal microRNA system. Nat. Rev. Neurosci. 2006, 7, 911-920. [CrossRef] [PubMed]

8. Kalra, H.; Simpson, R.J.; Ji, H.; Aikawa, E.; Altevogt, P.; Askenase, P.; Bond, V.C.; Borràs, F.E.; Breakefield, X.; Budnik, V.; et al. Vesiclepedia: A compendium for extracellular vesicles with continuous community annotation. PLoS Biol. 2012, 10, e1001450. [CrossRef]

9. Gomes, A.R.; Sangani, N.B.; Fernandes, T.G.; Diogo, M.M.; Curfs, L.M.G.; Reutelingsperger, C.P. Extracellular Vesicles in CNS Developmental Disorders. Int. J. Mol. Sci. 2020, 21, 9428. [CrossRef] [PubMed]

10. Yan, S.; Zhang, H.; Xie, W.; Meng, F.; Zhang, K.; Jiang, Y.; Zhang, X.; Zhang, J. Altered microRNA profiles in plasma exosomes from mesial temporal lobe epilepsy with hippocampal sclerosis. Oncotarget 2017, 8, 4136-4146. [CrossRef]

11. Li, N.; Pan, J.; Liu, W.; Li, Y.; Li, F.; Liu, M. MicroRNA-15a-5p serves as a potential biomarker and regulates the viability and apoptosis of hippocampus neuron in children with temporal lobe epilepsy. Diagn. Pathol. 2020, 15, 46. [CrossRef]

12. Li, L.; Liu, C.Q.; Li, T.F.; Guan, Y.G.; Zhou, J.; Qi, X.L.; Yang, Y.T.; Deng, J.H.; Xu, Z.Q.; Luan, G.M. Analysis of Altered Micro RNA Expression Profiles in Focal Cortical Dysplasia IIB. J. Child Neurol. 2016, 31, 613-620. [CrossRef]

13. Lee, J.Y.; Park, A.K.; Lee, E.S.; Park, W.Y.; Park, S.H.; Choi, J.W.; Phi, J.H.; Wang, K.C.; Kim, S.K. miRNA expression analysis in cortical dysplasia: Regulation of mTOR and LIS1 pathway. Epilepsy Res. 2014, 108, 433-441. [CrossRef]

14. Wang, L.; Song, L.; Chen, X.; Suo, J.; Ma, Y.; Shi, J.; Liu, K.; Chen, G. microRNA-139-5p confers sensitivity to antiepileptic drugs in refractory epilepsy by inhibition of MRP1. CNS Neurosci. Ther. 2020, 26, 465-474. [CrossRef]

15. Elnady, H.G.; Abdelmoneam, N.; Eissa, E.; Hamid, E.R.A.; Zeid, D.A.; Abo-Shanab, A.M.; Atta, H.; Kholoussi, N.M. MicroRNAs as Potential Biomarkers for Childhood Epilepsy. Open Access Maced. J. Med. Sci. 2019, 7, 3965-3969. [CrossRef]

16. Ren, L.; Zhu, R.; Li, X. Silencing miR-181a produces neuroprotection against hippocampus neuron cell apoptosis post-status epilepticus in a rat model and in children with temporal lobe epilepsy. Genet. Mol. Res. 2016, 15. [CrossRef]

17. Omran, A.; Peng, J.; Zhang, C.; Xiang, Q.L.; Xue, J.; Gan, N.; Kong, H.; Yin, F. Interleukin-1 $\beta$ and microRNA-146a in an immature rat model and children with mesial temporal lobe epilepsy. Epilepsia 2012, 53, 1215-1224. [CrossRef]

18. Wu, X.; Wang, Y.; Sun, Z.; Ren, S.; Yang, W.; Deng, Y.; Tian, C.; Yu, Y.; Gao, B. Molecular expression and functional analysis of genes in children with temporal lobe epilepsy. J. Integr. Neurosci. 2019, 18, 71-77. [CrossRef]

19. Ashhab, M.U.; Omran, A.; Kong, H.; Gan, N.; He, F.; Peng, J.; Yin, F. Expressions of tumor necrosis factor alpha and microRNA-155 in immature rat model of status epilepticus and children with mesial temporal lobe epilepsy. J. Mol. Neurosci. 2013, 51, 950-958. [CrossRef]

20. Peng, J.; Omran, A.; Ashhab, M.U.; Kong, H.; Gan, N.; He, F.; Yin, F. Expression patterns of miR-124, miR-134, miR-132, and miR-21 in an immature rat model and children with mesial temporal lobe epilepsy. J. Mol. Neurosci. 2013, 50, 291-297. [CrossRef]

21. Brennan, G.P.; Bauer, S.; Engel, T.; Jimenez-Mateos, E.M.; Del Gallo, F.; Hill, T.D.M.; Connolly, N.M.C.; Costard, L.S.; Neubert, V.; Salvetti, B.; et al. Genome-wide microRNA profiling of plasma from three different animal models identifies biomarkers of temporal lobe epilepsy. Neurobiol. Dis. 2020, 144, 105048. [CrossRef]

22. Raoof, R.; Bauer, S.; El Naggar, H.; Connolly, N.M.C.; Brennan, G.P.; Brindley, E.; Hill, T.; McArdle, H.; Spain, E.; Forster, R.J.; et al. Dual-center, dual-platform microRNA profiling identifies potential plasma biomarkers of adult temporal lobe epilepsy. EBioMedicine 2018, 38, 127-141. [CrossRef]

23. Sun, J.; Cheng, W.; Liu, L.; Tao, S.; Xia, Z.; Qi, L.; Huang, M. Identification of serum miRNAs differentially expressed in human epilepsy at seizure onset and post-seizure. Mol. Med. Rep. 2016, 14, 5318-5324. [CrossRef]

24. Surges, R.; Kretschmann, A.; Abnaof, K.; van Rikxoort, M.; Ridder, K.; Fröhlich, H.; Danis, B.; Kaminski, R.M.; Foerch, P.; Elger, C.E.; et al. Changes in serum miRNAs following generalized convulsive seizures in human mesial temporal lobe epilepsy. Biochem. Biophys. Res. Commun. 2016, 481, 13-18. [CrossRef]

25. Korotkov, A.; Broekaart, D.W.M.; Banchaewa, L.; Pustjens, B.; van Scheppingen, J.; Anink, J.J.; Baayen, J.C.; Idema, S.; Gorter, J.A.; van Vliet, E.A.; et al. microRNA-132 is overexpressed in glia in temporal lobe epilepsy and reduces the expression of pro-epileptogenic factors in human cultured astrocytes. Glia 2020, 68, 60-75. [CrossRef]

26. Guo, J.; Wang, H.; Wang, Q.; Chen, Y.; Chen, S. Expression of p-CREB and activity-dependent miR-132 in temporal lobe epilepsy. Int. J. Clin. Exp. Med. 2014, 7, 1297-1306. 
27. Reschke, C.R.; Silva, L.F.A.; Norwood, B.A.; Senthilkumar, K.; Morris, G.; Sanz-Rodriguez, A.; Conroy, R.M.; Costard, L.; Neubert, V.; Bauer, S.; et al. Potent Anti-seizure Effects of Locked Nucleic Acid Antagomirs Targeting miR-134 in Multiple Mouse and Rat Models of Epilepsy. Mol. Ther. Nucleic. Acids. 2017, 6, 45-56. [CrossRef]

28. Alsharafi, W.; Xiao, B. Dynamic Expression of MicroRNAs (183, 135a, 125b, 128, 30c and 27a) in the Rat Pilocarpine Model and Temporal Lobe Epilepsy Patients. CNS Neurol. Disord. Drug Targets. 2015, 14, 1096-1102. [CrossRef]

29. Alsharafi, W.A.; Xiao, B.; Li, J. MicroRNA-139-5p negatively regulates NR2A-containing NMDA receptor in the rat pilocarpine model and patients with temporal lobe epilepsy. Epilepsia 2016, 57, 1931-1940. [CrossRef]

30. Korotkov, A.; Broekaart, D.W.M.; van Scheppingen, J.; Anink, J.J.; Baayen, J.C.; Idema, S.; Gorter, J.A.; Aronica, E.; van Vliet, E.A. Increased expression of matrix metalloproteinase 3 can be attenuated by inhibition of microRNA-155 in cultured human astrocytes. J. Neuroinflammation 2018, 15, 211. [CrossRef]

31. Li, T.R.; Jia, Y.J.; Wang, Q.; Shao, X.Q.; Zhang, P.; Lv, R.J. Correlation between tumor necrosis factor alpha mRNA and microRNA155 expression in rat models and patients with temporal lobe epilepsy. Brain. Res. 2018, 1700, 56-65. [CrossRef]

32. Huang, L.G.; Zou, J.; Lu, Q.C. Silencing rno-miR-155-5p in rat temporal lobe epilepsy model reduces pathophysiological features and cell apoptosis by activating Sestrin-3. Brain. Res. 2018, 1689, 109-122. [CrossRef] [PubMed]

33. Zheng, H.; Tang, R.; Yao, Y.; Ji, Z.; Cao, Y.; Liu, Z.; Peng, F.; Wang, W.; Can, D.; Xing, H.; et al. MiR-219 Protects Against Seizure in the Kainic Acid Model of Epilepsy. Mol. Neurobiol. 2016, 53, 1-7. [CrossRef] [PubMed]

34. Antônio, L.G.L.; Freitas-Lima, P.; Pereira-da-Silva, G.; Assirati, J.A., Jr.; Matias, C.M.; Cirino, M.L.A.; Tirapelli, L.F.; Velasco, T.R.; Sakamoto, A.C.; Carlotti, C.G., Jr.; et al. Expression of MicroRNAs miR-145, miR-181c, miR-199a and miR-1183 in the Blood and Hippocampus of Patients with Mesial Temporal Lobe Epilepsy. J. Mol. Neurosci. 2019, 69, 580-587. [CrossRef] [PubMed]

35. Fu, H.; Cheng, Y.; Luo, H.; Rong, Z.; Li, Y.; Lu, P.; Ye, X.; Huang, W.; Qi, Z.; Li, X.; et al. Silencing MicroRNA-155 Attenuates Kainic Acid-Induced Seizure by Inhibiting Microglia Activation. Neuroimmunomodulation 2019, 26, 67-76. [CrossRef]

36. Gong, G.H.; An, F.M.; Wang, Y.; Bian, M.; Wang, D.; Wei, C.X. MiR-153 regulates expression of hypoxia-inducible factor-1 $\alpha$ in refractory epilepsy. Oncotarget 2018, 9, 8542-8547. [CrossRef]

37. Che, N.; Zu, G.; Zhou, T.; Wang, X.; Sun, Y.; Tan, Z.; Liu, Y.; Wang, D.; Luo, X.; Zhao, Z.; et al. Aberrant Expression of miR-323a-5p in Patients with Refractory Epilepsy Caused by Focal Cortical Dysplasia. Genet. Test Mol. Biomark. 2017, 21, 3-9. [CrossRef]

38. Sun, Y.; Wang, X.; Wang, Z.; Zhang, Y.; Che, N.; Luo, X.; Tan, Z.; Sun, X.; Li, X.; Yang, K.; et al. Expression of microRNA-129-2-3p and microRNA-935 in plasma and brain tissue of human refractory epilepsy. Epilepsy Res. 2016, 127, 276-283. [CrossRef]

39. Li, Y.; Huang, C.; Feng, P.; Jiang, Y.; Wang, W.; Zhou, D.; Chen, L. Aberrant expression of miR-153 is associated with overexpression of hypoxia-inducible factor- $1 \alpha$ in refractory epilepsy. Sci. Rep. 2016, 6, 32091. [CrossRef]

40. Wang, X.; Sun, Y.; Tan, Z.; Che, N.; Ji, A.; Luo, X.; Sun, X.; Li, X.; Yang, K.; Wang, G.; et al. Serum MicroRNA-4521 is a Potential Biomarker for Focal Cortical Dysplasia with Refractory Epilepsy. Neurochem. Res. 2016, 41, 905-912. [CrossRef]

41. Wang, X.; Luo, Y.; Liu, S.; Tan, L.; Wang, S.; Man, R. MicroRNA-134 plasma levels before and after treatment with valproic acid for epilepsy patients. Oncotarget 2017, 8, 72748-72754. [CrossRef]

42. Haenisch, S.; von Rüden, E.L.; Wahmkow, H.; Rettenbeck, M.L.; Michler, C.; Russmann, V.; Bruckmueller, H.; Waetzig, V.; Cascorbi, I.; Potschka, H. miRNA-187-3p-Mediated Regulation of the KCNK10/TREK-2 Potassium Channel in a Rat Epilepsy Model. ACS Chem. Neurosci. 2016, 7, 1585-1594. [CrossRef] [PubMed]

43. Organista-Juárez, D.; Jiménez, A.; Rocha, L.; Alonso-Vanegas, M.; Guevara-Guzmán, R. Differential expression of miR-34a, 451, 1260, 1275 and 1298 in the neocortex of patients with mesial temporal lobe epilepsy. Epilepsy Res. 2019, 157, 106188. [CrossRef] [PubMed]

44. Shen, C.H.; Zhang, Y.X.; Zheng, Y.; Yang, F.; Hu, Y.; Xu, S.; Yan, S.Q.; Ding, Y.; Guo, Y.; Ding, M.P. Expression of plasma microRNA-145-5p and its correlation with clinical features in patients with refractory epilepsy. Epilepsy Res. 2019, 154, 21-25. [CrossRef] [PubMed]

45. An, N.; Zhao, W.; Liu, Y.; Yang, X.; Chen, P. Elevated serum miR-106b and miR-146a in patients with focal and generalized epilepsy. Epilepsy Res. 2016, 127, 311-316. [CrossRef] [PubMed]

46. Wang, J.; Tan, L.; Tan, L.; Tian, Y.; Ma, J.; Tan, C.C.; Wang, H.F.; Liu, Y.; Tan, M.S.; Jiang, T.; et al. Circulating microRNAs are promising novel biomarkers for drug-resistant epilepsy. Sci. Rep. 2015, 5, 10201. [CrossRef] [PubMed]

47. Leontariti, M.; Avgeris, M.; Katsarou, M.S.; Drakoulis, N.; Siatouni, A.; Verentzioti, A.; Alexoudi, A.; Fytraki, A.; Patrikelis, P.; Vassilacopoulou, D.; et al. Circulating miR-146a and miR-134 in predicting drug-resistant epilepsy in patients with focal impaired awareness seizures. Epilepsia 2020, 61, 959-970. [CrossRef] [PubMed]

48. Ioriatti, E.S.; Cirino, M.L.A.; Lizarte Neto, F.S.; Velasco, T.R.; Sakamoto, A.C.; Freitas-Lima, P.; Tirapelli, D.P.C.; Carlotti, C.G., Jr. Expression of circulating microRNAs as predictors of diagnosis and surgical outcome in patients with mesial temporal lobe epilepsy with hippocampal sclerosis. Epilepsy Res. 2020, 166, 106373. [CrossRef]

49. Martins-Ferreira, R.; Chaves, J.; Carvalho, C.; Bettencourt, A.; Chorão, R.; Freitas, J.; Samões, R.; Boleixa, D.; Lopes, J.; Ramalheira, J.; et al. Circulating microRNAs as potential biomarkers for genetic generalized epilepsies: A three microRNA panel. Eur. J. Neurol. 2020, 27, 660-666. [CrossRef]

50. Raoof, R.; Jimenez-Mateos, E.M.; Bauer, S.; Tackenberg, B.; Rosenow, F.; Lang, J.; Onugoren, M.D.; Hamer, H.; Huchtemann, T.; Körtvélyessy, P.; et al. Cerebrospinal fluid microRNAs are potential biomarkers of temporal lobe epilepsy and status epilepticus. Sci. Rep. 2017, 7, 3328. [CrossRef] 
51. Avansini, S.H.; de Sousa Lima, B.P.; Secolin, R.; Santos, M.L.; Coan, A.C.; Vieira, A.S.; Torres, F.R.; Carvalho, B.S.; Alvim, M.K.; Morita, M.E.; et al. MicroRNA hsa-miR-134 is a circulating biomarker for mesial temporal lobe epilepsy. PLoS ONE 2017, 12, e0173060. [CrossRef]

52. Wang, J.; Yu, J.T.; Tan, L.; Tian, Y.; Ma, J.; Tan, C.C.; Wang, H.F.; Liu, Y.; Tan, M.S.; Jiang, T.; et al. Genome-wide circulating microRNA expression profiling indicates biomarkers for epilepsy. Sci. Rep. 2015, 5, 9522. [CrossRef] [PubMed]

53. Chen, M.; Zhao, Q.Y.; Edson, J.; Zhang, Z.H.; Li, X.; Wei, W.; Bredy, T.; Reutens, D.C. Genome-wide microRNA profiling in brain and blood samples in a mouse model of epileptogenesis. Epilepsy Res. 2020, 166, 106400. [CrossRef] [PubMed]

54. Okamoto, K.; Fukuda, M.; Saito, I.; Horiuchi, I.; Okazawa, T.; Ishii, E. Incidence of childhood epilepsy: A population-based study in rural Japan. Brain. Dev. 2018, 40, 904-908. [CrossRef]

55. Uldall, P.; Alving, J.; Hansen, L.K.; Kibaek, M.; Buchholt, J. The misdiagnosis of epilepsy in children admitted to a tertiary epilepsy centre with paroxysmal events. Arch. Dis. Child 2006, 91, 219-221. [CrossRef]

56. Coppola, A.; Moshé, S.L. Why is the developing brain more susceptible to status epilepticus? Epilepsia 2009, 50, 25-26. [CrossRef] [PubMed]

57. Pitkänen, A.; Lukasiuk, K. Molecular and cellular basis of epileptogenesis in symptomatic epilepsy. Epilepsy Behav. 2009, 14, 16-25. [CrossRef] [PubMed]

58. Liu, D.Z.; Tian, Y.; Ander, B.P.; Xu, H.; Stamova, B.S.; Zhan, X.; Turner, R.J.; Jickling, G.; Sharp, F.R. Brain and blood microRNA expression profiling of ischemic stroke, intracerebral hemorrhage, and kainate seizures. J. Cereb. Blood Flow Metab. 2010, 30, 92-101. [CrossRef] [PubMed]

59. Roncon, P.; Zucchini, S.; Ferracin, M.; Marucci, G.; Giulioni, M.; Michelucci, R.; Rubboli, G.; Simonato, M. Is autopsy tissue a valid control for epilepsy surgery tissue in microRNA studies? Epilepsia Open 2016, 2, 90-95. [CrossRef]

60. McKiernan, R.C.; Jimenez-Mateos, E.M.; Bray, I.; Engel, T.; Brennan, G.P.; Sano, T.; Michalak, Z.; Moran, C.; Delanty, N.; Farrell, M.; et al. Reduced mature microRNA levels in association with dicer loss in human temporal lobe epilepsy with hippocampal sclerosis. PLoS ONE 2012, 7, e35921. [CrossRef] [PubMed]

61. Bencurova, P.; Baloun, J.; Musilova, K.; Radova, L.; Tichy, B.; Pail, M.; Zeman, M.; Brichtova, E.; Hermanova, M.; Pospisilova, S.; et al. MicroRNA and mesial temporal lobe epilepsy with hippocampal sclerosis: Whole miRNome profiling of human hippocampus. Epilepsia 2017, 58, 1782-1793. [CrossRef]

62. Hicks, S.D.; Ignacio, C.; Gentile, K.; Middleton, F.A. Salivary miRNA profiles identify children with autism spectrum disorder, correlate with adaptive behavior, and implicate ASD candidate genes involved in neurodevelopment. BMC Pediatr. 2016, 16, 52. [CrossRef] [PubMed]

63. Liguori, M.; Nuzziello, N.; Licciulli, F.; Consiglio, A.; Simone, M.; Viterbo, R.G.; Creanza, T.M.; Ancona, N.; Tortorella, C.; Margari, L.; et al. Combined microRNA and mRNA expression analysis in pediatric multiple sclerosis: An integrated approach to uncover novel pathogenic mechanisms of the disease. Hum. Mol. Genet. 2018, 27, 66-79. [CrossRef] [PubMed]

64. Jimenez-Mateos, E.M.; Engel, T.; Merino-Serrais, P.; McKiernan, R.C.; Tanaka, K.; Mouri, G.; Sano, T.; O'Tuathaigh, C.; Waddington, J.L.; Prenter, S.; et al. Silencing microRNA-134 produces neuroprotective and prolonged seizure-suppressive effects. Nat. Med. 2012, 18, 1087-1094. [CrossRef] [PubMed]

65. Jimenez-Mateos, E.M.; Engel, T.; Merino-Serrais, P.; Fernaud-Espinosa, I.; Rodriguez-Alvarez, N.; Reynolds, J.; Reschke, C.R.; Conroy, R.M.; McKiernan, R.C.; deFelipe, J.; et al. Antagomirs targeting microRNA-134 increase hippocampal pyramidal neuron spine volume in vivo and protect against pilocarpine-induced status epilepticus. Brain. Struct. Funct. 2015, 220, $2387-2399$. [CrossRef]

66. Zhou, X.; Chen, J.; Tao, H.; Cai, Y.; Huang, L.; Zhou, H.; Chen, Y.; Cui, L.; Zhong, W.; Li, K. Intranasal Delivery of miR-155-5p Antagomir Alleviates Acute Seizures Likely by Inhibiting Hippocampal Inflammation. Neuropsychiatr. Dis. Treat. 2020, 16, 1295-1307. [CrossRef]

67. Hu, K.; Xie, Y.Y.; Zhang, C.; Ouyang, D.S.; Long, H.Y.; Sun, D.N.; Long, L.L.; Feng, L.; Li, Y.; Xiao, B. MicroRNA expression profile of the hippocampus in a rat model of temporal lobe epilepsy and miR-34a-targeted neuroprotection against hippocampal neurone cell apoptosis post-status epilepticus. BMC Neurosci. 2012, 13, 115. [CrossRef]

68. Sano, T.; Reynolds, J.P.; Jimenez-Mateos, E.M.; Matsushima, S.; Taki, W.; Henshall, D.C. MicroRNA-34a upregulation during seizure-induced neuronal death. Cell Death Dis. 2012, 3, e287. [CrossRef]

69. Jimenez-Mateos, E.M.; Bray, I.; Sanz-Rodriguez, A.; Engel, T.; McKiernan, R.C.; Mouri, G.; Tanaka, K.; Sano, T.; Saugstad, J.A.; Simon, R.P.; et al. miRNA Expression profile after status epilepticus and hippocampal neuroprotection by targeting miR-132. Am. J. Pathol. 2011, 179, 2519-2532. [CrossRef]

70. Wang, X.; Yin, F.; Li, L.; Kong, H.; You, B.; Zhang, W.; Chen, S.; Peng, J. Intracerebroventricular injection of miR-146a relieves seizures in an immature rat model of lithium-pilocarpine induced status epilepticus. Epilepsy Res. 2018, 139, 14-19. [CrossRef]

71. Zhang, H.L.; Lin, Y.H.; Qu, Y.; Chen, Q. The effect of miR-146a gene silencing on drug-resistance and expression of protein of P-gp and MRP1 in epilepsy. Eur. Rev. Med. Pharmacol. Sci. 2018, 22, 2372-2379. [CrossRef]

72. Iori, V.; Iyer, A.M.; Ravizza, T.; Beltrame, L.; Paracchini, L.; Marchini, S.; Cerovic, M.; Hill, C.; Ferrari, M.; Zucchetti, M.; et al. Blockade of the IL-1R1/TLR4 pathway mediates disease-modification therapeutic effects in a model of acquired epilepsy. Neurobiol. Dis. 2017, 99, 12-23. [CrossRef] [PubMed]

73. Henshall, D.C. Manipulating MicroRNAs in Murine Models: Targeting the Multi-Targeting in Epilepsy. Epilepsy Curr. 2017, 17, 43-47. [CrossRef] [PubMed] 
74. Huang, Y.; Liu, X.; Liao, Y.; Luo, C.; Zou, D.; Wei, X.; Huang, Q.; Wu, Y. MiR-181a influences the cognitive function of epileptic rats induced by pentylenetetrazol. Int. J. Clin. Exp. Pathol. 2015, 8, 12861-12868. [PubMed]

75. Schouten, M.; Fratantoni, S.A.; Hubens, C.J.; Piersma, S.R.; Pham, T.V.; Bielefeld, P.; Voskuyl, R.A.; Lucassen, P.J.; Jimenez, C.R.; Fitzsimons, C.P. MicroRNA-124 and -137 cooperativity controls caspase-3 activity through BCL2L13 in hippocampal neural stem cells. Sci. Rep. 2015, 5, 12448. [CrossRef] [PubMed] 